\title{
Sexually transmitted diseases in children in developing countries
}

\author{
J Richens
}

Most of the world's children live in developing countries where their right to protection from sexual exploitation and abuse under Article 34 of the UN Convention on the Rights of the Child is far more vulnerable to infringement than is the case for children in affluent countries. Although the situation is very poorly documented, there are many reasons to believe that not only the pattern of sexually transmitted diseases (STDs) differs in the developing world but also that children are affected on a far greater scale than they are in the West. In this review I shall examine the available evidence in support of these statements as well as studies that relate to specific STDs in children in developing countries. For further discussion of ophthalmia neonatorum, congenital syphilis, lymphogranuloma venereum and HIV infection in children earlier articles in this series ${ }^{1-3}$ and other reviews ${ }^{45}$ should be consulted.

\section{Sources}

Standard computer searches of the medical literature, cross-checked with references from other review articles were used to identify all pertinent articles. Additional items on donovanosis were identified through the author's (unpublished) comprehensive bibliography of donovanosis. The literature on sexual exploitation of children in the tropics is fragmentary and mostly to be found in reports by UN and charitable agencies working with children; items were identified through a recent publication by Redd Barna, the Norwegian Save the Children ${ }^{6}$ and with assistance from Kevin Ireland, research co-ordinator, UK Save the Children.

\section{Incidence}

The high incidence of STDs in adult populations in developing countries has been well documented in surveys of STDs in antenatal mothers ${ }^{7}$ and correlates with the high frequency of congenital syphilis and ophthalmia neonatorum reported from these countries. ${ }^{8}$ The patterns of sexual behaviour described in studies from developing countries, particularly in more modern urban societies, show similar trends to those reported in industrialised countries, ie increasingly early age of first sexual intercourse, longer intervals between onset of sexual activity and marriage and increasing numbers of sexual partners. ${ }^{9}$ The frequency of STDs in younger age groups in developing countries is not well documented but can be gauged indirectly by reported experience of STD in surveys of adolescents and young adults. The validity of such studies is not well established and caution should be exercised in generalising the findings to other populations. A recent study from Uganda reported that, among those aged $15-24$ years, $21 \cdot 4 \%$ of males and $7 \cdot 8 \%$ of females had experience of a sexually transmitted infection. ${ }^{10}$ In Nigeria, Sogbetun et al found that $31(21.5 \%)$ of 144 female patients referred to their clinic with STDs over a $2 \frac{1}{2}$ year period were girls under the age of $10 .{ }^{11}$ In a separate STD clinic-based study from Nigeria gonorrhoea was diagnosed in 115 females, $36.5 \%$ of whom were aged 1-12 years. ${ }^{12}$ It has recently been reported from Uganda that $33 \%$ of female patients and $12 \%$ of males attending for treatment of STDs are children. ${ }^{13}$ To some extent these figures can be explained on purely demographic grounds; given a high incidence of STDs in adults and a proportion of the population made up of children and sexually active young adults that is much higher in developing countries than in developed countries, a relatively high incidence of STDs in children may be expected. A number of other potentially important factors are discussed below.

\section{Sexual abuse}

A small number of studies of medical aspects of child sexual abuse have been reported from developing countries. The principal findings of studies from Jamaica, ${ }^{14}$ Papua New Guinea $^{15}$ and South Africa ${ }^{16}{ }^{17}$ are given in the table. From these studies it is apparent these children are most likely to come to medical attention a result of genital trauma. A rather smaller proportion of children present with symptoms of STDs. The importance of genital trauma in sexually abused children has been further highlighted by J. M. Wynne, a paediatric surgeon, working in South Africa. ${ }^{18}$ Wynne has described the injuries seen in a series of 24 raped female children, aged 15 months to 12 years (average age 6 years) over a 4 year period at the Livingstone Hospital, Port Elizabeth. The injuries ranged from external bruising and vulval lacerations to extensive internal tears extending into the rectum or abdomen. The article highlights the need for carefully determining the exact nature of the injuries, preferably by examination under anaesthetic, and for meticulous early repair wherever possible.

\section{Sexual exploitation of children in developing} countries

Whereas in affluent countries STDs in children are closely associated with sexual abuse where the perpetrator is most often someone

\author{
London W1N 8AA, UK \\ J Richens \\ Accepted for publication \\ 10 January 1994 \\ Academic \\ Medicine, University \\ School of Medicine, \\ James Pringle House,
}


Table Principal findings in studies of child sexual abuse in developing countries

\begin{tabular}{|c|c|c|c|c|c|c|c|c|c|c|c|c|}
\hline $\begin{array}{l}\text { No. of } \\
\text { cases }\end{array}$ & Setting & Age range & $\begin{array}{l}\text { Average } \\
\text { age } \\
\text { (years) }\end{array}$ & $\begin{array}{l}\text { Female } \\
(\%)\end{array}$ & $\begin{array}{l}\text { Discharge } \\
\text { (\%) }\end{array}$ & $\begin{array}{l}\text { Total } \\
\text { with } \\
\text { STD } \\
(\%)\end{array}$ & $\begin{array}{l}\text { Gonorrhoea } \\
(\%)\end{array}$ & $\begin{array}{l}\text { Syphilis } \\
\text { (\%) }\end{array}$ & $\begin{array}{l}\text { Genital } \\
\text { warts } \\
(\%)\end{array}$ & $\begin{array}{l}\text { Genital } \\
\text { trauma (\%) }\end{array}$ & $\begin{array}{l}\text { Perpe- } \\
\text { trator } \\
\text { known to } \\
\text { victim (\%) }\end{array}$ & Ref. \\
\hline 20 & $\begin{array}{l}\text { Children's } \\
\text { hospital }\end{array}$ & 2-12 years & $5 \cdot 5$ & $16(80)$ & $\mathrm{NA}^{\star}$ & $2(10)$ & $1(5)$ & $1(5)$ & 0 & $11(55)$ & $13(65)$ & 16 \\
\hline 33 & $\begin{array}{l}\text { Cases reported } \\
\text { to Family } \\
\text { Court }\end{array}$ & $2-16$ years & $8 \cdot 3$ & $30(91)$ & NA & $5(15)$ & $5(15)$ & 0 & 0 & $3(9)$ & $27(93)$ & 14 \\
\hline 88 & $\begin{array}{l}\text { Children's } \\
\text { Hospital }\end{array}$ & $\begin{array}{l}10 \text { months } \\
-13 \text { years }\end{array}$ & $6 \cdot 5$ & $79(90)$ & $10(11)$ & $17(19)$ & $9(10)$ & $8(9)$ & 0 & $40(45)$ & $41(47)$ & 17 \\
\hline 23 & $\begin{array}{l}\text { Paediatric } \\
\text { outpatients }\end{array}$ & NA & NA & $20(87)$ & $5(22)$ & $7(30)$ & $3(13)$ & $1(4)$ & $3(13)$ & $12(52)$ & $14(61)$ & 15 \\
\hline
\end{tabular}

^NA-not available.

known by the abused child, it appears likely that this problem is eclipsed in several developing countries by the sexual exploitation of children for commercial gain. In recent years there has been a growing concern expressed particularly by charitable organisations working with children in developing countries about this issue.

The problem is best known in South-east Asia where it emerged in the wake of the Vietnam war and has, since 1975, been sustained by a massive increase in a form of tourism in which opportunities for sexual adventure have been a key marketing point. An estimated $20 \%$ of prostitutes in this region are below the age of 15 years. ${ }^{6}$ It is impossible at present to state accurately what the scale of the problem is, as estimates vary enormously. Suffice it to say that charitable and UN agencies working in this field have reported an "explosion" in the numbers of girls and boys brought into prostitution associated with tourism $^{19}$ which has led to international campaigns such as ECPAT (End Child Prostitution in Asia Tourism) and international conferences. A valuable recent publication from Redd Barna, the Norwegian Save the Children Fund, comments on the situation in urban environments in Philippines, Kenya, Peru, Thailand, India and Sri Lanka. The number of children engaged in prostitution was estimated at 20000 in the Philippines, 15-20000 in Thailand and $300-400000$ in India. ${ }^{6}$

Sexual exploitation of children occurs in a number of settings. There are an estimated 100-200 million street children worldwide, many of whom sell sex to survive. Amongst 310 street children interviewed in Tanzania $85 \%$ stated they had been forced to practice sex for economic gain or from peer pressure. ${ }^{20}$ Other children are involved in organised prostitution, many of whom live in appalling conditions, highlighted by the recent incident where several children died in a fire in a Phuket brothel because they were chained to their beds. Trafficking of children from Burma, Laos and China into Thailand for organised prostitution has been reported. Kenya and Nigeria are examples of countries where girls from poor families are engaged at an early age as housemaids by more wealthy families and become particularly vulnerable to various forms of exploitation which may include sexual abuse, often by young male members of the household and visitors. Some of the African studies of vulvovaginitis in children have identified infected housemaids as a likely source of infection for young children in the same household, ${ }^{12}$ and it has been suggested by others that abused housemaids may, in their turn abuse children in their care. ${ }^{21}$ Once pregnant, housemaids are likely to be dismissed, and, unable to return to their families, end up in prostitution. Other especially vulnerable groups are children of prostitutes ( 5 million in India alone according to one estimate ${ }^{6}$ ) and those in refugee camps.

The clients of children in prostitution include significant numbers of local people as well as tourists and travelling businessmen. Countries such as Thailand, Philippines and Sri Lanka are well known to both homosexual and heterosexual paedophiles from affluent countries and information about particular places circulates in underground paedophile networks. The small Philippine town of Pagsanjan was estimated to have 3000 young boys in prostitution in the late 1970's catering for up to 2000 overseas tourists daily, half of whom were thought to be paedophiles. ${ }^{22}$ The extent to which adults without strong paedophile preferences have sex with these under-age children is not known but studies like those of Briere and Runtz, who reported that of 193 male university students in the United States, $21 \%$ admitted sexual attraction to small children, $9 \%$ described sexual fantasies involving children and $7 \%$ indicated the likelihood of having sex with a child if they could avoid detection and punishment, ${ }^{23}$ support the notion that many of the clients of child prostitutes are not exclusively paedophile.

The question of STDs in sexually exploited children has not been seriously addressed yet. There is abundant anecdotal evidence that such children suffer as one would expect them to do in a setting where they have sex with many partners from an adult population with a high incidence of STDs. Children may be targetted specifically by clients who do not want to use condoms. Twenty six of $85(30.6 \%)$ girls under the age of 17 years, rescued from brothels by the Thai Centre for the Protection of Children's Rights tested HIV + ve, according to their 1991 annual report. ${ }^{24} \mathrm{HIV}$ seropositivity was $7 \%$ amongst 100 street boys 
aged 6-14 years tested in Khartoum in $1988^{25}$ and 35\% amongst certain subpopulations of Brazilian street youth. ${ }^{26}$ In view of the situation described above, it is important that discussion of HIV transmission in children in the tropics should be broadened beyond the issues of vertical transmission and transmission through blood products to include sexual transmission. Transmission of HIV by child sex abuse has already received attention in the United States. ${ }^{27}$ It is likely to be of much greater importance in countries where sexual exploitation of children is common.

\section{Cultural factors}

A number of cultural factors that increase the risk of a child's exposure to STD have been described. A well known example is the belief, reported from countries in Africa as widely separated as Nigeria ${ }^{28}$ and Rwanda, ${ }^{29}$ that a male with urethritis can be cured by sexual contact with a virgin or prepubertal girl. Of particular concern recently are reports of an increased demand for sex with children by clients who believe that sex with children carries a lower risk of acquiring HIV. In India sexual abuse of girls is uniquely linked to religious ritual in the devadasi system whereby girls from poor families are dedicated to the goddess, Yellema, at an early age and auctioned off at puberty to a wealthy bidder at a temple auction. The highest bidder takes the girl home as a concubine for a year or so following which the girl, who is forbidden to marry, usually leaves the household and enters prostitution. India has an estimated 100000 devadasi with 5-10000 new recruits annually. It is thought $90 \%$ go into prostitution. ${ }^{6}$ The contribution of ritual homosexual practices to donovanosis in children in Papua New Guinea is discussed in the section on donovanosis.

\section{STD patterns in the tropics}

The bacterial STDs are relatively more important and genital ulcer disease is common. The size of the emerging HIV epidemic is rapidly overtaking that in affluent countries. Diseases such as chancroid, lymphogranuloma venereum and donovanosis (granuloma inguinale) are mainly to be found in tropical latitudes.

One of the few recent surveys of STD in children in developing countries comes from Zambia. Ratnam et al reported on 26 children (18 female) under the age of 15 years referred to an STD clinic over a 20 month period during which 15000 adult patients attended. ${ }^{30}$ Sixteen of the 19 patients under 10 years were female whilst five of the seven older children were male. Eight of the 18 female patients were considered victims of sexual assault whilst the remaining 10 acquired their infection through sexual experimentation with adolescent or preadolescent males. Fifteen of the females were reported as having intact hymens. Secondary syphilis was diagnosed in 17 patients $(65.4 \%)$, trichomoniasis in nine, gonorrhoea in five and genital warts in four. The authors emphasise that the children referred to their clinic probably represent a highly selected group with the more florid manifestations of symptomatic STDs. In contrast with the high incidence of syphilis in Zambia, the majority of children seen in Nigerian STD clinic based studies have been girls with gonococcal vulvovaginitis (see below).

\section{Vulvovaginitis}

In communities with a high incidence of gonorrhoea, significant numbers of prepubertal girls with vulvovaginitis are likely to be encountered. The number of prepubertal girls with vaginal discharge seen at the Centre Hospitalier de Kigali, Rwanda over a four year period was given as 301 in an important recently reported study. ${ }^{29}$ In a study reported from a Nigerian STD clinic $35 \%$ of female patients with gonorrhoea were girls under the age of twelve years with vulvovaginitis. ${ }^{12}$ In a study from Malaysia $3.8 \%$ of 406 cases of gonorrhoea in females occurred in children under 12 years of age. ${ }^{31}$ The frequency of isolation of $N$ gonorrhoeae from prepubertal girls with vulvovaginitis in the tropics varies from $35 \%$ of the 301 relatively unselected girls studied in Rwanda to $94.1 \%$ of the 17 girls studied in a Nigerian STD clinic by Osoba and Alausa. ${ }^{28}$ Important observations made in the Rwanda study were that $30 \%$ of gonococcal isolates were $\beta$-lactamase-producing and that Shigella isolates appeared to account for the discharge in $6.3 \%$ of patients. The authors concluded that Shigella, which hitherto has rarely been acknowledged as a cause of vaginal discharge, may be of importance in populations where shigellosis is common. Furthermore, treatment with intramuscular ceftriaxone proved unsatisfactory in a number of cases infected with Shigella and nalidixic acid or cotrimoxazole proved more satisfactory.

The possibility that $N$ gonorrhoeae in tropical settings is more likely to be transmitted by non-venereal means has been examined in a number of studies, although these were mostly conducted before the importance of child sexual abuse had received the much wider recognition it now has. In the studies reported from Southern Nigeria, the authors have suggested that the humid environment, and frequent sharing of clothes, towels and bedding by children and infected adults provide ideal conditions for non-sexual transmission of $N$ gonorrhoeae. ${ }^{32}$ Potential transmission of $N$ gonorrhoeae through sharing of towels or clothing with infected adults was identified in up to $24 \%$ of the 17 paediatric cases reported by Osoba and Alausa. ${ }^{28}$ It has been suggested that herpes simplex type 2 can be transmitted under similar circumstances by the authors of studies from Nigeria ${ }^{33}$ and India $^{34}$ which showed inexplicably high levels of antibody to herpes simplex type 2 in small children. As discussed in an earlier article in this series, ${ }^{1}$ it is unwise to infer non-venereal transmission of STDs solely on the basis of infected family members and unhygienic conditions in the household. Warnings to adults 
about contaminating children with infected fomites may be appropriate in some settings but should not deflect attention from the possibility that children have been sexually abused. Bello's study from Zaria in the drier climate of Northern Nigeria found evidence of sexual transmission in nine of eleven girls studied. ${ }^{35}$ The authors of the Rwanda study state that sexual abuse was suspected by the mothers of all the children studied although physical evidence of abuse was not demonstrated. The diagnosis of gonococcal vulvovaginitis in a prepubertal girl certainly warrants efforts to identify further cases in the same household. In the study by Alausa and Osoba $^{12} 83$ household contacts were examined (29 male) and 18 further cases of gonorrhoea came to light (4 male). Cooperation from males was substantially less than that of females.

\section{Donovanosis (granuloma inguinale)}

Donovanosis is an ulcerative disease of the anogenital area largely confined to a handful of endemic foci in tropical latitudes. The principal foci occur in Papua New Guinea, India, South Africa and Brazil; in many parts of the tropics the disease is seldom seen. Although the disease is rarely reported in children, there is no doubt that children are susceptible to infection and significant numbers of infected children have been reported in the course of major epidemics of donovanosis that occurred in New Guinea. ${ }^{36} 37$ The causative organism is an intracellular gram-negative coccobacillus called Calymmatobacterium granulomatis.

While there is abundant evidence that the disease is usually sexually transmitted, at least one leading authority has suggested that the organism is an inhabitant of the bowel that acts as an opportunist invader of the anogenital region. ${ }^{38}$ The diagnosis is made by demonstration of Donovan bodies in material taken from lesions. A variety of broad-spectrum antibiotics are effective in treatment, the most popular of which are tetracyclines. Non-venereal transmission to extragenital sites has been fairly well documented in individual cases. In a case described by Thierfelder, a boy developed a lesion of the ear lobe following a piercing procedure in which the instrument used had been previously employed by an adult with donovanosis to dilate a urethral stricture. ${ }^{39}$ There is potential for perinatal transmission, although this appears to be rare. The most important case report of perinatal transmission was reported from the USA in $1952 .{ }^{40}$ In this report a child was born to a mother with an untreated donovanosis lesion of the uterine cervix. At 5 months of age the child developed a purulent discharge from the right ear with a tympanic perforation and postauricular swelling. Subsequently lesions of the umbilicus and penis appeared together with a lytic bone lesion of the right radius. Histological examination of the lesions confirmed the presence of donovan bodies and the infection was successfully eradicated with streptomycin. This case indicates a potentially lengthy incubation period for perinatally acquired donovanosis, and illustrates the capacity of donovanosis to disseminate haematogenously to bone and to produce cutaneous lesions at sites with delicate skin or mucosae such as the ears, umbilicus and genitalia. There are additional case reports of donovanosis on the umbilicus of a six-week infant born to a mother with extensive lesions of the vulva and perineum ${ }^{41}$ and on the labia of a six month female infant whose mother's condition is not reported. ${ }^{42}$ Taken together these reports suggest that children born to mothers with untreated lesions of donovanosis should undergo careful cleansing of the ears, umbilicus and genitalia and perhaps be given a prophylactic antibiotic such as erythromycin in order to minimise the risk of perinatal infection.

Infection of children in the course of epidemics of donovanosis has been reported from New Guinea. The most spectacular of these epidemics affected the Marind-anim of the then Dutch New Guinea around 1920. Substantial numbers of children became infected and it was noted that young adolescent males frequently developed perianal infections. This observation was linked to the ritual homosexual practices in which adolescent males were subject, over a 2-year period, to regular anal penetration by an older man, traditionally one of their mother's brothers, in the belief that regular insemination was required to bring young males to full maturity. ${ }^{43}$ The pattern of infection in children reported by Zigas in a separate epidemic in the Goilala district of the Papuan Mountains ${ }^{37}$ was quite different. In a survey of infected cases, it was found that 14 of the 343 occurred among children aged 1-4 years. Commenting on this, Zigas has suggested that the infection was passed from infected adults to children sitting on their scantily clad laps.

The difficulties of diagnosing donovanosis in settings where the disease is now unfamiliar is well illustrated by a case in a poor white adolescent from the United States, published under the telling subtitle "A diagnosis easily forgotten, poorly pursued." 44

Freinkel has published an intriguing report from South Africa in which he describes donovanosis presenting as enlarged cervical lymph nodes simulating tuberculosis in an 11 year-old boy and a 16-year old girl. ${ }^{45}$

\section{Chancroid}

Infections due to Haemophilus ducreyi constitute the most common cause of genital ulcer disease in many surveys reported from developing countries. Despite the high frequency of such infections this disease, which is characterised by the development of painful, purulent genital ulcers, often accompanied by bubo formation, has not been reported in neonates or children. To some extent this may be explained by the very limited availability of specialised culture techniques required for cultivation of $H$ ducreyi in settings where the infection is common. In their review of STDs in children, Neinstein $e t a l^{46}$ were unable to cite any case reports of chancroid in children. 
Amongst the 70 Eskimo women with chancroid studied in the Greenland epidemic of 1977-8, two were aged between 10 and 14 years. ${ }^{47}$ Techniques for the demonstration of antibodies to $H$ ducreyi are currently being developed. In a recent study from Uganda, elevated titres of antibody to purified $H$ ducreyi lipooligosaccharide proved to be a highly sensitive and specific indicator of chancroid infection and were not found in any of 50 children studied. ${ }^{48}$

\section{Venereal and non-venereal treponematosis}

While, in the majority of settings, it is reasonable to assume that treponemal lesions of the anogenital region in children provide strong evidence of sexual activity, it is important to be aware that there are areas of the world where non-venereal transmission of the treponemal diseases known as yaws and endemic syphilis is commonplace, that endemic, nonvenereal treponematosis is predominantly a disease of children, and that in the secondary stage of these infections clustering of condylomata lata in moist areas, such as the anogenital region, simply reflects the susceptibility of moist skin folds for the development of papillomata and is no indication that the infection was initially transmitted sexually. The usual setting for endemic treponematosis is remote, impoverished rural communities. The history of treponematosis in Europe suggests that treponemal disease is readily transmitted to children by non-venereal means in conditions of crowding and poor hygiene. Although deprivation may be a contributing factor to the sexual abuse of children, the appearance of treponemal infection in children living in grossly unhygienic conditions in developed countries may occasionally result from direct, non-sexual contact of the child with an infected adult or contaminated household items. Transmission of endemic syphilis in Bosnia and Iraq was attributed in part to sharing of drinking vessels.

There is a widespread misperception that endemic treponematosis was eliminated by WHO mass treatment campaigns in the 1950 s and 1960s and has been replaced by venereal syphilis in the countries where it used to occur. In fact, in several parts of Africa and South East Asia yaws control programmes were disbanded after the initial successes and in some areas yaws endemicity has returned to pre-campaign levels while much of the expertise built up in previous control campaigns has been lost. ${ }^{49}$

Controversy has raged for decades as to whether non-venereal treponematosis is due to truly separate species of treponema, giving rise to truly distinguishable clinical features or whether yaws and bejel (endemic syphilis) are all due to $T$ pallidum with modification of the clinical expression by environmental factors such as patient age and local climate. Most textbooks continue to state that cardiovascular and neuro-ophthalmological complications of yaws as well as congenital transmission do not occur. Any careful examination of the pertinent literature shows that these statements are quite unwarranted.50 After decades of attempts to demonstrate morphological, immunological or genetic differences in isolates from yaws and syphilis patients, to date nothing more than a single, inconstant nucleotide substitution on one gene has been described..$^{51}$ The cogency of these findings has recently been acknowledged by taxonomists who have relegated the agent of yaws from Treponema pertenue to Treponema pallidum var. pertenue. ${ }^{52}$ In summary, where treponemal infection of children is common, the usual mode of transmission is non-venereal and this is reflected in the usual site for the initial lesion which is on the leg. A primary genital lesion suggests sexual transmission but secondary lesions of the anogenital region are liable to arise in all cases of untreated treponematosis regardless of how the infection was initially acquired.

\section{Prevention}

There is an urgent need for more widespread application of well-established measures for the prevention of congenital syphilis and ophthalmia neonatorum in the tropics. Recent work has shown that measures taken to prevent these conditions are highly cost-effective. ${ }^{53}$ Congenital syphilis is the more difficult to prevent effectively. Several studies have shown that a number of logistical difficulties have to be overcome in order to ensure not only that all mothers are tested but also that treatment is offered to all women who test positive..$^{5455}$ To achieve this it is generally necessary to provide facilities for testing in antenatal clinics so that same-day treatment can be offered.

A wide range of measures has been called for to combat the sexual exploitation and HIV/STD transmission amongst children in developing countries. The most important of these are covered in the general recommendations on clinical care, prevention, research needs, policy and legislative action formulated at the First International Conference of AIDS and Homeless Youth and summarised recently by Luna and Rotheram-Borus. ${ }^{5}$ The first task is to face up to the unpalatable facts, overcome the understandable disbelief and denial that this topic evokes, and force this subject higher up the international political agenda. Only then will it be possible to fund badly needed research and to introduce and enforce appropriate legislation in support of Article 34 of the UN convention on the rights of the child, which calls for the prevention of sexual exploitation of children. Only then will the current campaigns to rescue children from prostitution, to prevent sex-tourism, and to establish centres for the education and rehabilitation of street children receive the level of support required for them to make any real impact.

\section{Future research}

The dearth of useful information needs to be addressed with well-designed cross-sectional and longitudinal studies of HIV and STD morbidity and sexual and drug-using behav- 
iour of children involved in the informal or organised sale of sex in developing countries. With this information available, a wide range of intervention studies can be envisaged addressing the dissemination of information and condoms, and the provision of accessible and appropriate health services to vulnerable children.

1 Rawstron SA, Bromberg K, Hammerschlag MR. STD in children: syphilis and gonorrhoea. Genitourin Med 1993;69:66-75.

2 Goh BT, Forster GE. Sexually transmitted diseases in children: chlamydial oculogenital infection. Genitourin Med 1993;69:213-21.

3 Mok JYQ. Sexually transmitted diseases in children: HIV infection. Genitourin Med 1992;68:283-9.

4 Quinn TC, Ruff A, Halsey N. Pediatric acquired immunodeficiency syndrome: special considerations for developing nations. Pediatr Infect Dis $¥ 1992 ; 11: 558-68$.

5 Luna GC, Rotheram-Borus MJ. Street youth and the AIDS pandemic. AIDS Educ Prev 1992;4(Suppl):1-13.

6 Ove Narvesen. The sexual exploitation of children in developing countries. Oslo, Redd Barna, 1989

7 Antal GM. The epidemiology of sexually transmitted diseases in the tropics. In: Osoba AO, ed. Baillière's Clinical Tropical Medicine and Communicable Diseases: International Practice and Research, Volume 2, Number 1, 1987. Sexually Transmitted Diseases in the Tropics, London: Baillière Tindall, 1987.

8 Schulz KF, Cates W Jr, O'Mara PR. Pregnancy loss, infant death, and suffering: legacy of syphilis and gonorrhoea in death, and suffering: legacy of syphilis and

9 Carael M, Cleland J, Adeokun L. Overview and selected findings of sexual behaviour surveys. AIDS 1991; 5(Suppl 1):S65-74

10 Agyei WKA, Epema EJ, Lubega M. Contraception and prevalence of sexually transmitted disease among adolescents and young adults in Uganda. Int $\mathcal{f}$ Epidemio 1992;21:981-8.

11 Sogbetun AO, Alausa KO, Osoba AO. Sexually transmitted diseases in Ibadan, Nigeria. $\mathrm{Br} f$ Venereal Di 1977;53:155-60.

12 Alausa KO, Osoba AO. Epidemiology of gonococcal vulvovaginitis among children in the tropics. $\mathrm{Br} f$ Venereal Dis 1980;56:239-42.

13 Mukisa E, Rubagiza J. Ugandan children attending the national STD clinic; why they are at risk of KIV/STDs. IXth International Conference on AIDS, Berlin, June 6-11, 1993: abstract PO-C20-3064.

14 Eldemire D. Sexual abuse of children in Kingston and St Andrew, Jamaica. $W$ Ind Med $\mathcal{f} 1986 ; 35: 38-43$.

15 McClelland A, Polume $H$. Sexual abuse of children presenting to the children's outpatient department of Por Moresby General Hospital. Papua New Guinea Med $\mathcal{Y}$ 1990;33:203-6.

16 Westcott DL. Sexual abuse of children. $S$ Afr Med $f$ 1984;65:895-7.

17 Jaffe AM, Roux P. Sexual abuse of children-a hospitalbased study. $S$ Afr Med $\mathcal{F} 1988 ; 74: 65-7$.

18 Wynne JM. Injuries to the genitalia in female children. $S$ Afr Med $₹$ 1980;57:47-50.

19 UN/ESCAP. Promotion of community awareness for the prevention of prostitution. New York UN, 1991.

20 Vivian SM, Iruganyuma BM. Street children and HIV/AIDS intervention programme in Tanzania. VIIth IIV/AIDS intervention programme in Tanzania. VIIth International Conference on AIDS in Africa, 1992, Final

21 Okeahialam TC. Child abuse in Nigeria. Child Abuse Neglect 1984;8:69-73.

22 Aquino E. Tourism and child prostitution in Pagsanjan Philippines). Pagsanjan Rural Organization for Development (ROAD), 1987.

23 Briere J, Runtz M. University males' sexual interest in children: predicting potential indices of "paedophilia" in a nonforensic sample. Child Abuse Neglect 1989;13:65-75.

24 Centre for Protection of Children's Rights. Report on Child Rights Violations: Annual Report to 31 December 1991, CPCR, Bangkok, Thailand, 1991.

25 Dalglish P. Action for children, Vol 3, No 2. UNICEF, 1988.

26 Cavalho C. HIV epidemiologic study of minors. Brazilian $\mathcal{F}$ Med 1989;56:3.
27 Gutman LT, St Clair KK, Weedy C, Herman-Giddens ME, Lane BA, Niemeyer JG, McKinney RF. Human immunodeficiency virus transmission by child sexual abuse. Am ₹ Dis Child 1991;145:137-41.

28 Osoba AO, Alausa KO. Vulvovaginitis in Nigerian children. Nigerian $\mathcal{F}$ Paed 1973;1:26-32.

29 Bogaerts J, Lepage P, De Clercq A, Mukeshimana M Serufilira A, Piot P, Verhaegen J. Shigella and gonococcal vulvovaginitis in prepubertal central African girls. Ped Inf vis $₹ 1992 ; 11: 890-2$.

30 Ratnam AV, Haworth A, Hira SK. Sexually transmitted diseases in children. East Afr Med $\mathcal{F} 1983 ; 60$ :636-9.

31 Ismail R, Toh CK, Ngeow YF. Gonococcal vulvovaginitis among female children in Malaysia. Sex Transm Dis $1985 ; 12: 114-6$

32 Alausa KO, Sogbetun AO, Montefiore D. Effect of drying on Neisseria gonorrhoeae in relation to non-venereal infection in children. Nigerian $\mathcal{F}$ Paediatr 1977;4:14-8.

33 Sobgetun AO, Montefiore D, Anong CN. Herpesvirus hominis antibodies among children and young adults in Ibadan. Br $₹$ Venereal Dis 1979;55:44-7.

34 Seth P, Sundaram KR, Samantaray JC, Prakash SS Seroepidemiology study of herpes simplex virus types and 2 in Delhi. Ind $\Im$ Med Res $1981 ; 73: 475-83$.

35 Bello CSS. Gonococcal vulvo-vaginitis in children: the Zaria experience. Nigerian $\mathcal{F}$ Paediatr 1982;9:75-9.

36 Kalthofen A. De bestrijding van het venerisch granuloom onder de Kaja-Kaja's van Nederlands-Zuid-Nieuwonder de Kaja-Kaja's van Nederlands-Zuid-1

37 Zigas V. A donovanosis project in Goilala (1951-1954) Papua New Guinea Med F 1971;14:148-9.

38 Goldberg J. Studies on granuloma inguinale. VII. Some epidemiological considerations of the disease. $\mathrm{Br} \mathcal{F}$ Venereal Dis 1964;40:140-5.

39 Thierfelder MU. Extragenitale Infektion mit venerischen Granulom. In: Festschrift Bernhard Nocht, Arbeiten über Tropenkrankheiten, Hamburg, Friedrichsen 1927:553-5.

40 Scott CW, Harper D, Jason RS, Helwig EP. Neonatal granuloma venereum. Am $\mathcal{f}$ Dis Child 1952;85:308-15.

41 Arnell RE, Potekin JS. Granuloma inguinale (granuloma venereum) of the cervix. An analysis of thirty-eight cases. Am $₹$ Obstet Gynecol 1940;39:626-35.

42 Banerjee $\mathrm{K}$. Donovanosis in a child of six months. F Ind Med Assoc 1972;59:293.

43 Vogel L, Richens J. Donovanosis in Dutch South New Guinea: history, evolution of the epidemic and control. Papua New Guinea Med f 1989;32:203-18.

44 Growdon WA, Lebherz TB, Moore JG, Mason GD, Parks G, Goldman L. Granuloma inguinale in a white teenager-a diagnosis easily forgotten, poorly pursued. West $\mathcal{F}$ Med 1985;143:105-8.

45 Freinkel AL. Granuloma inguinale of cervical lymph nodes simulating tuberculous lymphadenitis: two case reports and review of published reports. Genitourin Med 1988; 64:339-43.

46 Neinstein LS, Goldenring J, Carpenter S. Nonsexual transmission of sexually transmitted diseases: an infretransmission of sexually transmitted diseas

47 Lykke-Olesen L, Pedersen TG, Larsen L, Gaarslev K Epidemic of chancroid in Greenland 1977-78. Lancet 1979;1:654-5

48 Alfa M, Olson N, Degagne P, Plummer F, Namaara W, Maclean I, Ronald AR. Humoral immune response of humans of lipooligosaccharide and outer membrane proteins of Haemophilus ducreyi. F Infect Dis 1993;167: 1206-10.

49 Meheus A, Antal GM. The endemic treponematoses: not yet eradicated. World Health Stat $O$ 1992;45:228-37.

50 Roman GC, Roman LN. Occurrence of congenital, cardiovascular, visceral, neurologic, and neuro-ophthalmologic complications in late yaws: a theme for future research. Rev Infect Dis 1986;8:760-70.

51 Noordhoek GT, Wieles B, van der Sluis JJ, van Embden JD. Polymerase chain reaction and synthetic DNA probes: a means of distinguishing the causative agents of syphilis and yaws? Infect Immunol 1990;58:2011-3.

52 Smibert RM. Genus III Treponema Schaudinn 1905 1728AL. In: Kreig, NR, Holt JG, eds. Bergey's Manua of Systematic Bacteriology. Baltimore: Williams \& Wilkins, 1984:49-75.

53 Over M, Piot P. HIV infection and STDs. In: Jamison DT, Mosley WH eds. Disease Control Priorities in Developing Countries New York: Oxford University Press, in press.

54 Guinness LF, Sibandze $S$, McGrath $E$ Cornelis AL Influence of antenatal screening on perinatal mortality Influence of antenatal screening on perinatal mortality 64:294-7.

55 McKown RR, Kapernick PS. Syphilis and pregnancy. South Med f 1988;81:447-51. 